Neth. J. Pl. Path. 87 (1981) 217-232

\title{
Damage effects of cereal aphids in wheat
}

R. RABBINGE, E.M. DREES, M. VAN DER GRAAF, F.C.M. VERBERNE and A. WESSELO

Department of Theoretical Production Ecology, Agricultural University, Wageningen

Accepted 5 March 1981

\begin{abstract}
Laboratory and field studies on aphid damage in wheat are described. Both direct and indirect effects of aphids on the behaviour of the crop were studied. In the laboratory a clear effect of honeydew and yeasts on photosynthesis was found. This effect could not be demonstrated under field conditions, since even at yield loss levels of $700 \mathrm{~kg} \mathrm{ha}^{-1}$ the size of this effect may be undetectable with crop enclosures reaching an accuracy of $10 \%$. The effect of honeydew on ageing, measured in the laboratory trials was also found in the field and may form a major cause of the yield losses found in the field. Yield losses under field conditions reached $700 \mathrm{~kg}$ $\mathrm{ha}^{-1}$ and were for $72 \%$ due to direct sucking damage of the 35 aphids, found maximally per culm, and direct and indirect honeydew effects. Saprophytic and possibly also some necrotrophic fungi caused $28 \%$ of the yield losses. The exact contribution of each of the damage factors was not revealed but it was demonstrated that direct and indirect effects contribute to the final yield losses.
\end{abstract}

Additional keywords: Sitobion avenae, Metopolophium dirhodum, Cryptococcus laurentii var. flavescens, Cladosporium spp., Sporobolomyces roseus, Aureobasidium pullulans, honeydew, damage-threshold, ageing of leaves, photosynthesis, Entomophthora, winter wheat.

\section{Introduction}

Aphids have caused considerable damage to cereals the last decade. This has stimulated research on the population dynamics of aphids and on the damage they cause, the results of which have been reviewed by Vickerman and Wratten (1979) and Carter et al. (1980).

The increased importance of cereal aphids may have resulted from changes in wheat cultivation: high sowing densities, a prolonged maturation period resulting from split and top gifts of $\mathrm{N}$-fertilizers at flowering, and an increase in use of herbicides and fungicides. The latter may have reduced the number of natural enemies of aphids (Vickerman and Sunderland, 1977), so that cereal aphids can achieve more of their biotic potentials on plants that now remain favourable for aphids for a longer period than previously.

The increase in cereal aphid numbers has led to an increase in the use of aphicides virtually unknown until the sixties. To prevent a further increase in the use of pesticides, and spraying of wheat as an insurance a soundly based control system may be useful. Furthermore it is necessary to consider critically the mentioned developments which have caused the increase of aphid numbers. 
Economic thresholds for certain pests and diseases are already in use, but they are unreliable for aphids because of the low correlation between aphid abundance and loss of yield (Rabbinge and Mantel, 1981). Further information is needed on the cause of the loss in yield and the way growth and productivity of a wheat crop and the number of aphids are affected by weather. Population studies have given good descriptions and reliable simulation models for the upsurge and flattening of population growth of Sitobion avenae (Rabbinge et al., 1979; Carter and Rabbinge, 1980; Carter et al., in prep.). The poor reliability of the warning system is especially due to a lack in knowledge of the nature and background of yield loss and the way the crop-aphid relation is affected by environmental factors.

Aphids can have both a direct and indirect effect on plant growth. Consumption of assimilates by aphids explains only part of the total reduction in yield. The quantity of phloem sap ingested by aphids depends on the nitrogen content of the sap (Wratten, 1975; Vereijken, 1979). A high nitrogen level results in a fall in the rate of consumption of sap per aphid and in less honeydew being produced per aphid, it promotes aphid growth, increases the reproductive rate, shortens development time and inhibits wing formation in cereal aphids (Vereijken, 1979). The net effect of a rich food supply can be a greater drain inflicted by a better thriving aphid population (Wratten, 1978).

Indirect effects of aphids may be due to their sugary excreta: honeydew. This can cover large areas of a plant's epidermis and may hamper photosynthesis and promote senescence (Bardner and Fletcher, 1974); it promotes the growth of saprophytic fungi which may also have a negative effect on photosynthesis and leaf duration (Vereijken, 1979). These indirect effects, however, are scarcely investigated.

In this paper the results are presented of a laboratory study on the effects of honeydew, aphids and yeasts on photosynthesis and ageing of leaves. A field study is presented of the effects of aphids and saprophytic fungi on cereal yield along with some preliminary observations on the effect of aphids and saprophytic fungi on photosynthesis in the field. The saprophytic fungi that were studied under field conditions comprise black moulds (Cladosporium spp., and Aureobasidium pullulans), white yeasts (Cryptococcus spp.), red yeasts (Sporobolomyces roseus). Under laboratory conditions only white yeasts have been used.

\section{Materials and methods}

\section{A. Laboratory trials}

Plant material, aphid rearing, fungal cultures. Summer wheat (cv. Opal) was grown in sandy loam in $25 \mathrm{~cm}$ diameter Mitscherlich pots, weight $5 \mathrm{~kg}$, and kept in a glasshouse $\left(12^{\circ} \mathrm{C}, 70 \% \mathrm{r}\right.$.h. and a daylength of $16 \mathrm{~h}$, light intensity varied between $60-90$ $\mathrm{W} \mathrm{m}^{-2}$ ) during the first 2-3 months and afterwards in a phytotron under constant conditions (during the day r.h. $60 \%, 16^{\circ} \mathrm{C}$, during the night r.h. $70 \%, 14^{\circ} \mathrm{C}$ (group A) or $13^{\circ} \mathrm{C}$ (group B), and daylength $17 \mathrm{~h}(\mathrm{~A})$ or $15 \mathrm{~h}(\mathrm{~B})$ ). Plants were pruned to one tiller per plant and 15 plants per pot. Nitrogen conditions were abundant as a result of an initial gift of $2 \mathrm{~g}$ ammoniumnitrate and additional gifts of $2 \mathrm{~g}$ ammoniumnitrate per pot in plant stage Fe 10.5.1. in group A (Feekes scale for cereal development stages, Large, 1954), and four gifts of $2 \mathrm{~g}$ ammoniumnitrate before plant stage Fe 10.5.1. in group B. 
All experiments were done with the English grain aphid Sitobion avenae. Apterous aphids were taken from a mass rearing of $S$. avenae at the Laboratory of Entomology (Ankersmit et al., in prep.) on seedlings.

Honeydew used in the experiments was collected from a culture of $S$. avenae feeding on seedlings and kept in leaf cages for 10-14 days (Vereijken, 1979). The honeydew adhering to the perspex walls of the cages was collected by washing the cages in a small amount of water. After washing and filtration the honeydew solution was freeze dried and weighed. The dry weight of honeydew produced per aphid per day varied from $0.052 \mathrm{mg}$ to $0.188 \mathrm{mg}$.

In the experiment for the direct effect of the aphids, a standardization procedure was applied; apterous adult aphids, the off spring of aphids reared individually from birth in leaf cages, were used.

The yeast Cryptococcus laurentii var. flavescens, which is very common on wheat leaves, was supplied by Dr N.J. Fokkema, Phytopathological Laboratory 'Willie Commelin Scholten', Baarn (the Netherlands) and reared on potato-dextrose agar.

Treatments. To measure the effect of honeydew, aphids and yeasts on photosynthesis and ageing of the leaves the following treatments were used:

Effects of honeydew on photosynthesis and ageing. Flag leaves were treated manually by spreading droplets of honeydew solution (10\% honeydew in water) on the epidermis, introduced by a droplet pipet. Either the upper side (UP) or under side (UN) (circa $0.1 \mathrm{mg}$ honeydew (HD) per $\mathrm{cm}^{2}$ ) were treated. Each treatment (Table 1) was repeated 6 times. A photosynthesis-light response curve of the flag-leaves, 4 leaves per measurement, was measured using an infra-red $\mathrm{CO}_{2}$ analyser (Louwerse and Van Oorschot, 1969), immediately after the introduction of the honeydew (D) or one week later (W). Simultaneously $\mathrm{CO}_{2}$ assimilation and transpiration were measured.

Ageing of flag leaves treated with honeydew at either sides, was determined visually by estimating the rate at which the leaves turned yellow. This was done by measuring the length of the yellow top and the total length of the leaf. In one case these observations were compared with scanning reflection and transmission measurements.

Direct effects of aphids on photosynthesis. The direct effect of aphids on photosynthesis was determined by placing 5 apterous adult aphids on each plant and rearing them for 10 days. Sixty replicates were needed to overcome the variability in population growth. After 10 days, the number of aphids present, their age and morph composition and weight were determined and a photosynthesis-light response curve was measured. Thus a short and a heavy infestation of aphids was reached excluding the adverse effects of honeydew produced by these aphids on photosynthesis as this compound was catched by the walls of the small cages.

Effects of sugar solution and yeast-cell suspension on photosynthesis. Photosynthesis measurements were done on flag leaves sprayed with a sugar solution or a yeast/sugar suspension circa 5 days earlier. Sugar solution was added to initiate the growth of the yeast population. 


\section{B. Field experiments}

To determine the effects of aphids, honeydew and saprophytic fungi on yield and photosynthesis of winter wheat (cv. Arminda) under field conditions a field experiment has been done in 1979 at an experimental farm situated at Randwijk near Wageningen on heavy river clay. The experiment was laid out as a block scheme (6 parallels per treatment). The treatments were:

A. Infestation with a relatively small number of laboratory-reared cereal aphids (S. avenae and $M$. dirhodum) at late flowering (Fe 10.5.3, 4 July); no control measures against cereal aphids or saprophytic fungi.

B. Infestation with a relatively small number of cereal aphids at flowering; no control measures against cereal aphids; control of saprophytic fungi, by spraying Goldion (mancozeb, $5 \mathrm{~kg} \mathrm{ha}^{-1}$ ) on 4 July and Orthodifolatan (captafol $3.6 \mathrm{~kg} \mathrm{ha}^{-1}$ ) on 19 July (Fe 11.1).

C. Control of aphids by spraying Pirimor (pirimicarb $0.25 \mathrm{~kg} \mathrm{ha}^{-1}$ ) on 4 July (late flowering, Fe 10.5.3) and on 23 July (milky ripe); control of saprophytic fungi by spraying Goldion $\left(5 \mathrm{~kg} \mathrm{ha}^{-1}\right)$ on 4 July and Orthodifolatan $\left(3.6 \mathrm{~kg} \mathrm{ha}^{-1}\right)$ on $19 \mathrm{July}$;

D. Spraying of saprophytic fungi (Cladosporium cladosporides, Cryptococcus laurentii var. flavescens and Sporobolomyces roseus) suspended in a solution of whey powder $\left(2 \frac{1}{2} \%\right)$; control of cereal aphids by spraying Pirimor $\left(0.25 \mathrm{~kg} \mathrm{ha}^{-1}\right)$ on 4 July and 23 July. The fungal suspension was sprayed on 21 June, 4 and 11 July. The concentration of the fungal suspension is given in Table 1.

Table 1. Concentration of fungal solution suspension (in cells $\mathrm{cm}^{-3}$ ) used in the $\mathrm{D}$ treatment of the field experiment.

\begin{tabular}{|c|c|c|c|}
\hline Date & Red yeasts & White yeasts & $\begin{array}{l}\text { Cladosporium } \\
\text { cladosporides }\end{array}$ \\
\hline 21 June & $0.85 \times 10^{7}$ & $1 \times 10^{7}$ & $2.6 \times 10^{7}$ \\
\hline 4 July & $14 \times 10^{7}$ & $14 \times 10^{7}$ & $9.4 \times 10^{7}$ \\
\hline 11 July & $18 \times 10^{7}$ & $18 \times 10^{7}$ & $6.3 \times 10^{7}$ \\
\hline
\end{tabular}

Tabel 1. Concentratie van de schimmelsuspensie (in cellen $\mathrm{cm}^{-3}$ ) die werd gebruikt in behandeling $D$ van de veldproef.

The treatments were started on 4 July, after the flowering of wheat (Fe 10.5.3). As a check of the effectiveness of the treatments the fungal populations were determined weekly by culturing propagules, washed from 6 flag leaves per parallel; after the leaf area determination these leaves were cut into small pieces and shaken vigorously in water and the number of propagules in suspension determined by plating on agar for 3 days following the method of Fokkema et al. (1979a). The results are expressed in numbers of propagules per species $\mathrm{cm}^{-2}$ of cereal leaf. Total aphid numbers were estimated by counting twice a week aphids on 50 culums (main shoot and tillers) per parallel (Rabbinge and Mantel, 1981). The absolute number of aphids and the number of aphid-days (the integrated number of aphids in course of time) per culm was determined relative to time and developmental stage of the crop (Rautapåa, 1966). 
The yield of grain was found by harvesting a small subplot $(1.5 \mathrm{~m}$ by $10 \mathrm{~m})$ per replicate using a precision combine and then determining the weight of the grain per ha, and the 1000 kernel weight, both with $16 \%$ humidity from which the number of kernels $\mathrm{m}^{-2}$ could be calculated.

To test whether the effect on photosynthesis and ageing found in the laboratory occurs in the field, measurements of photosynthesis were made on the standing crop with a crop enclosure using mobile field equipment (Louwerse and Eikhoudt, 1975).

After these measurements (in most cases 2 days of continuous photosynthesis measurements) were made, each plot was harvested and the leaf area was determined. The measured figures were used in a computer program which calculates the amount of photosynthesis in $\mathrm{kg} \mathrm{CO}_{2} \mathrm{ha}^{-1} \mathrm{~h}^{-1}$ at various light intensities. The leaf area figures gave an indication of ageing of the canopy in course of time.

\section{Results}

\section{A. Laboratory trials}

Light response curves for each of the different treatments were analysed in the following way: the light response curve of initial leaves was used to calculate the light use efficiency $(\varepsilon)$ and the maximum rate of assimilation $\left(\mathrm{P}_{\max }\right)$ by means of a rectilinear hyperbola (1) (De Wit, 1965)

$\mathrm{P}=\frac{\mathrm{P}_{\max } \times \varepsilon \times \mathrm{I}}{\varepsilon \times \mathrm{I}+\mathrm{P}_{\max }}$

or a negative exponential satiation curve

$\mathrm{P}=\mathrm{P}_{\max } \times\left(1-\mathrm{e}^{-\frac{\varepsilon \times \mathrm{I}}{\mathrm{P}_{\max }}}\right)$

where $\mathrm{I}=$ incoming radiation in $\mathrm{J} \mathrm{m}^{-2} \mathrm{~S}^{-1}$ and $\mathrm{P}=$ gross photosynthesis in $\mathrm{kg} \mathrm{CO}_{2}$ $\mathrm{ha}^{-1} \mathrm{~h}^{-1}$ (Goudriaan and van Laar, 1978). $\varepsilon$ and $\mathrm{P}_{\max }$ can be estimated directly from the curves or by use of a standard optimization technique (OPTPAC).

To evaluate the effect of a change in the photosynthesis-light response curve on daily production of a crop and to compare the different treatments, the measured data were introduced in a simulation model (Goudriaan and van Laar, 1978) which calculates the daily production in $\mathrm{kg}$ dry mass ha ${ }^{-1}$ for an overcast and for a clear sky in June. The simulation model was run for a canopy with a leaf area index (LAI) of 1 . In the field leaf area indices are usually higher, but the difference between treatments will be fairly well represented.

Effects of honeydew on photosynthesis. Results of the measurements and calculations are given in Tables 2 and 3 . Table 2 gives the maximum leaf photosynthesis $\left(\mathrm{P}_{\max }\right)$ and the light use efficiency $(\varepsilon)$ obtained from the photosynthesis-light response curves. The asymptotic exponential formula (2) gave a better fit than the rectangular

Neth. J. Pl. Path. 87 (1981)

221 
hyperbola and is used. Both the maximum assimilation rate and light use efficiency were affected by the treatments. The experimental plants of all treatments were significantly different from the control plants (t-test, $\alpha=0.10)$. The consequences of these effects for the daily photosynthetic rate of a canopy with LAF = 1 under clear skies and overcast skies are given in Table 3. Again, all treatments differed significantly from the control (t-test, $\alpha=0.05$ ).

Table 2. Estimates of average maximum gross photosynthesis in $\mathrm{kg} \mathrm{CO}_{2} \mathrm{ha}^{-1} \mathrm{~h}^{-1}\left(\mathrm{P}_{\max }\right)$ and light use efficiency in $\mathrm{kg} \mathrm{CO}_{2} \mathrm{~s} \mathrm{~m}^{2} \mathrm{ha}^{-1} \mathrm{~h}^{-1} \mathrm{~J}^{-1}(\varepsilon)$ with a standard optimization technique (OPTPAC), in (wheat) leaves treated with honeydew.

\begin{tabular}{|c|c|c|c|c|c|c|}
\hline \multirow[b]{2}{*}{ Treatment } & \multirow[b]{2}{*}{$\mathrm{P}_{\max }$} & \multirow[b]{2}{*}{ st.dev. $P_{\max }$} & \multirow[b]{2}{*}{$\varepsilon$} & \multirow[b]{2}{*}{ st.dev. $\varepsilon$} & \multicolumn{2}{|c|}{ (normalized control $=100$ ) } \\
\hline & & & & & $\mathrm{P}_{\max }$ & $\mathcal{E}$ \\
\hline Control & 24.5 & 4.3 & 0.39 & 0.09 & 100 & 100 \\
\hline HDUPD $^{\mathrm{a}}$ & 23.3 & 3.8 & 0.31 & 0.05 & 95 & 80 \\
\hline HDUND $^{a}$ & 21.7 & 2.3 & 0.33 & 0.07 & 89 & 85 \\
\hline HDUPW $^{\mathrm{a}}$ & 20.6 & 2.3 & 0.33 & 0.09 & 84 & 84 \\
\hline HDUNW $^{\mathrm{a}}$ & 18.5 & 3.7 & 0.27 & 0.05 & 75 & 68 \\
\hline
\end{tabular}

a For explanation of abbreviated treatments, see text (page 219).

Tabel 2. Gemiddelde maximale bruto fotosynthese $\left(P_{\text {max }}\right)$ in $\mathrm{kg} \mathrm{CO}_{2} \mathrm{ha}^{-1} \mathrm{uur}^{-1}$ en de lichtbenuttingsefficiëntie (E) met een berekende standaard optimalisatietechniek (OPTPAC) in (tarwe)bladeren behandeld met honingdauw.

Table 3. Average daily gross photosynthesis in $\mathrm{kg} \mathrm{CO}_{2} \mathrm{ha}^{-1}$ day ${ }^{-1}$ (in (wheat) leaves treated with honeydew) computed with a simulation model for a day in June with completely overcast or completely clear sky of a canopy with leaf area index $(\mathrm{LAI})=1$.

\begin{tabular}{|c|c|c|c|c|c|c|}
\hline \multirow[t]{2}{*}{ Treatment } & \multicolumn{2}{|c|}{ Overcast } & \multicolumn{2}{|l|}{ Clear } & \multicolumn{2}{|c|}{ (normalized control $=100$ ) } \\
\hline & $\bar{X}$ & s.d. & $\bar{X}$ & s.d. & & \\
\hline Control & 169.5 & 28.0 & 282.4 & 41.5 & 100 & 100 \\
\hline HDUPD $^{a}$ & 134.7 & 21.3 & 248.5 & 38.7 & 79 & 88 \\
\hline HDUND $^{\mathrm{a}}$ & 142.4 & 17.8 & 245.5 & 24.5 & 84 & 87 \\
\hline HDUPW $^{\mathrm{a}}$ & 138.3 & 22.4 & 242.1 & 21.9 & 82 & 86 \\
\hline HDUNW $^{\mathrm{a}}$ & 124.5 & 13.0 & 212.1 & 26.6 & 73 & 75 \\
\hline
\end{tabular}

a For explanation of abbreviated treatments, see text (page 219).

Tabel 3. Gemiddelde dagelijkse bruto fotosynthese in $\mathrm{kg} \mathrm{CO}_{2} \mathrm{ha}^{-1}$ dag-1 (in (tarwe)bladeren behandeld met honingdauw) berekend met een gewassimulatiemodel, voor een volledig heldere en een volledig bewolkte hemel op een dag in juni van een gewas met bladoppervlakteindex $(L A I)=1$.

One week after the treatment the effect was even slightly greater (HDUPW, HDUNW). This was not due to a larger area of leaf being covered with honeydew, but might be due to the effect of honeydew on the ageing of the leaves. Because of 
climatic conditions (a relatively low air humidity), the saprophytic mycoflora on the leaves with or without honeydew was poorly developed, which excludes interference with fungal effects in these experiments.

The leaf area covered with honeydew was determined by measuring the covered and uncovered surface in a leaf area meter. The leaf area covered with honeydew varied from $46 \%$ to $85 \%$ (treatments HDUPD and HDUNW, respectively). As the under side (3700 stomata $\mathrm{cm}^{-2}$ ) and upper side (5600 stomata $\mathrm{cm}^{-2}$ ) of the leaves have a different number of stomates, the percentage of stomates covered is not proportional with the covered area at different sides, and thus $33 \%$ and $28 \%$, respectively of the stomata were covered with honeydew.

Effects of the treatment on the ageing of leaves. The greater effect on photosynthesis of the honeydew treatment one week after its application could result from the honeydew increasing the rate of ageing of the leaves. This should be revealed by the effect of honeydew on the yellowing of leaves (Table 4). The area of yellow leaf increased more rapidly for leaves treated with honeydew than for control leaves. Preliminary measurements of light transmission and reflectance 48 days after treatment gave the same indication (6\% reduction of absorption). Chlorophyll components seem to degenerate more rapidly in leaves covered with honeydew than in control leaves. Although these effects were small, their impact on crop production may be considerable, since during the grain filling period, a wheat crop has a net growth rate of $200 \mathrm{~kg}$ dry matter ha-1 $\mathrm{day}^{-1}$. A decrease in the length of this period will have a proportional effect on crop yield.

Table 4. Yellowing of leaves treated with honeydew.

\begin{tabular}{llllll}
\hline $\begin{array}{l}\text { Time } \\
\text { (days after } \\
\text { treatment) }\end{array}$ & \multicolumn{2}{l}{ Yellowinga) } & & t-test $\alpha$ \\
\cline { 2 - 5 } & control & & & treated \\
& $\bar{X}$ & s.d. & $\bar{X}$ & s.d. & \\
0 & 0 & - & & & \\
11 & 2.50 & 0.75 & 2.08 & 0.62 & 0.10 \\
39 & 6.04 & 1.28 & 7.21 & 1.65 & 0.05 \\
63 & 55.84 & 23.03 & 59.24 & 24.43 & - \\
\hline
\end{tabular}

a) Calculated by: $\mathrm{X}=$ (length yellow leaf surface/total length leaf) $\times 100$.

Tabel 4. Vergeling van bladeren die met honingdauw behandeld zijn.

Direct effects of aphids on photosynthesis. A separate treatment was used to determine the direct effects of aphids on photosynthesis. Aphid numbers, population age structure and aphid weight are given in Table 5. The effect of the aphids on photosynthesis was positive (Table 5). Apparently the removal of assimilates by the aphids promotes the assimilation rate. 
Table 5. Numbers and weight of aphids after 10 days (initial number 5 standard adult apterous aphids) in leaf cages and the effect of their presence on photosynthesis.

\begin{tabular}{|c|c|c|c|c|c|c|c|c|c|}
\hline \multirow[t]{4}{*}{ Treatment } & \multicolumn{4}{|c|}{ Developmental stages of aphids } & \multirow{4}{*}{$\begin{array}{l}\text { Total } \\
\text { aphid } \\
\text { weight } \\
\text { (mg) }\end{array}$} & \multirow{2}{*}{\multicolumn{4}{|c|}{$\begin{array}{l}\text { Daily gross photosynthesis } \\
\left(\mathrm{kg} \mathrm{CO}_{2} \mathrm{ha}^{-1} \text { day-1) }\right.\end{array}$}} \\
\hline & \multicolumn{2}{|c|}{ Adult apterous } & \multicolumn{2}{|c|}{ L1-L4 } & & & & & \\
\hline & \multirow{2}{*}{$\begin{array}{l}\text { num- } \\
\text { ber } \\
\frac{X}{X}\end{array}$} & \multirow{2}{*}{$\begin{array}{l}\text { weight } \\
(\mathrm{mg})\end{array}$} & \multirow{2}{*}{$\begin{array}{l}\text { num- } \\
\frac{\text { ber }}{X}\end{array}$} & \multirow{2}{*}{$\begin{array}{l}\text { weight } \\
\text { (mg) } \\
\bar{X}\end{array}$} & & \multicolumn{2}{|c|}{ overcast } & \multicolumn{2}{|l|}{ clear } \\
\hline & & & & & & $\overline{\mathrm{X}}$ & s.d. & $\overline{\mathrm{X}}$ & s.d. \\
\hline $\begin{array}{l}\text { Cages with } \\
\text { aphids }\end{array}$ & 16.6 & 16.8 & 218.3 & 37.8 & 54.6 & 173.7 & 42.7 & 316.9 & 83.6 \\
\hline $\begin{array}{l}\text { Control with } \\
\text { empty cages } \\
\text { Control }\end{array}$ & - & - & - & - & - & 156.5 & 26.8 & 282.0 & 50.8 \\
\hline without cages & - & - & - & - & - & 169.5 & 27.9 & 282.4 & 41.5 \\
\hline
\end{tabular}

Tabel 5. Aantallen en gewichten van bladluizen na 10 dagen (begin-aantal 5 standaardbladluizen) in bladkooien en het effect van de bladluizen op de fotosynthese.

Effects of yeast on photosynthesis. The sugar solution could affect the photosynthesis, but part of the sugar solution will be consumed by the yeast. Therefore, a comparison of the yeast cell suspension in a sugar solution, with a sugar solution and with water as controls is necessary to quantify the net effect. The respiration rate of the yeast itself, Cryptococcus spp. on water agar, was directly measured and proved to be negligible or unmeasurable with the equipment used. In Table 6 the results of the measurements are given. Comparison between treatment with sugar solution and treatment with sugar solution and yeast shows that there seems to be a negative effect of $9-11 \%$ on photosynthesis. However, a treatment with sugar solution without yeast also has a negative effect of $9-11 \%$ on photosynthesis, in comparison with untreated plants (control Table 6).

Table 6. Average gross photosynthesis in $\mathrm{kg} \mathrm{CO}_{2} \mathrm{ha}^{-1}$ day-1 (in leaves treated with yeast cells suspended in a sugar solution), calculated with a simulation model for a day in June with completely overcast or completely clear sky.

\begin{tabular}{|c|c|c|c|c|c|c|}
\hline \multirow[t]{2}{*}{ Treatment } & \multicolumn{2}{|c|}{ Overcast } & \multicolumn{2}{|l|}{ Clear } & \multicolumn{2}{|c|}{$\begin{array}{l}\text { Normalized treatment } \\
\text { with sugar solution }=100\end{array}$} \\
\hline & $\bar{X}$ & s.d. & $\bar{X}$ & s.d. & overcast & clear \\
\hline Control & 169.5 & 27.9 & 282.4 & 41.5 & 111 & 109 \\
\hline Sugar solution treatment & 152.9 & 21.9 & 259.3 & 15.5 & 100 & 100 \\
\hline treatment & 139.8 & 26.0 & 230.9 & 22.7 & 91 & 89 \\
\hline
\end{tabular}

Tabel 6. Gemiddelde dagelijkse bruto fotosynthese in $\mathrm{kg} \mathrm{CO}_{2} \mathrm{ha}^{-1}$ dag-1 (in bladeren behandeld met gistcellen gesuspendeerd in een suikeroplossing), berekend met een gewas-simulatiemodel voor een volledig bewolkte en een volledig heldere hemel op een dag in juni. 


\section{B. Field experiments}

Aphids and saprophytic fungi. On all plots counts were made of aphids and fungi to

check whether the application of aphids, fungi, aphicides and fungicides had been effective and to monitor the increase of aphids and fungi (Fig. 1a + b; Fig.2a + b). Cereal aphids were virtually absent from treatments $C$ and $D$ and abundant in treatments A and B. Both S. avenae and Metopolophium dirhodum reached high population densities in experimental plots A and B; the peak densities of both species were reached at the late milky ripe stage of cereal development. The significantly higher population density of aphids in treatment B (Kolmogorov-Smirnov test) in the second half of July is probably due to the application of captafol which killed aphid-infesting Entomophthora spp. and facilitated a more rapid increase in aphid numbers. The percentage of aphids infested with Entomophthora, i.e. the number of diseased aphids divided by the total number of living and dead aphids, is lower in B than in A plots (Fig. 1c + d).

Combining the results for $S$. avenae and $M$. dirhodum and calculating the number of aphid days (Rautapåa, 1966) gives 593 aphid days for B and 434 aphid days for A plots. This calculation does not take into account the changing age composition of

Fig. 1. Aphid density in course of time in field experiment after treatment A and B. Metopolophium dirhodum on leaves (1a) and percentage of these aphids attacked by Entomophthora (1c); Sitobion avenae on ears and leaves (1b) and percentage of these aphids attacked by Entomophthora (1d).

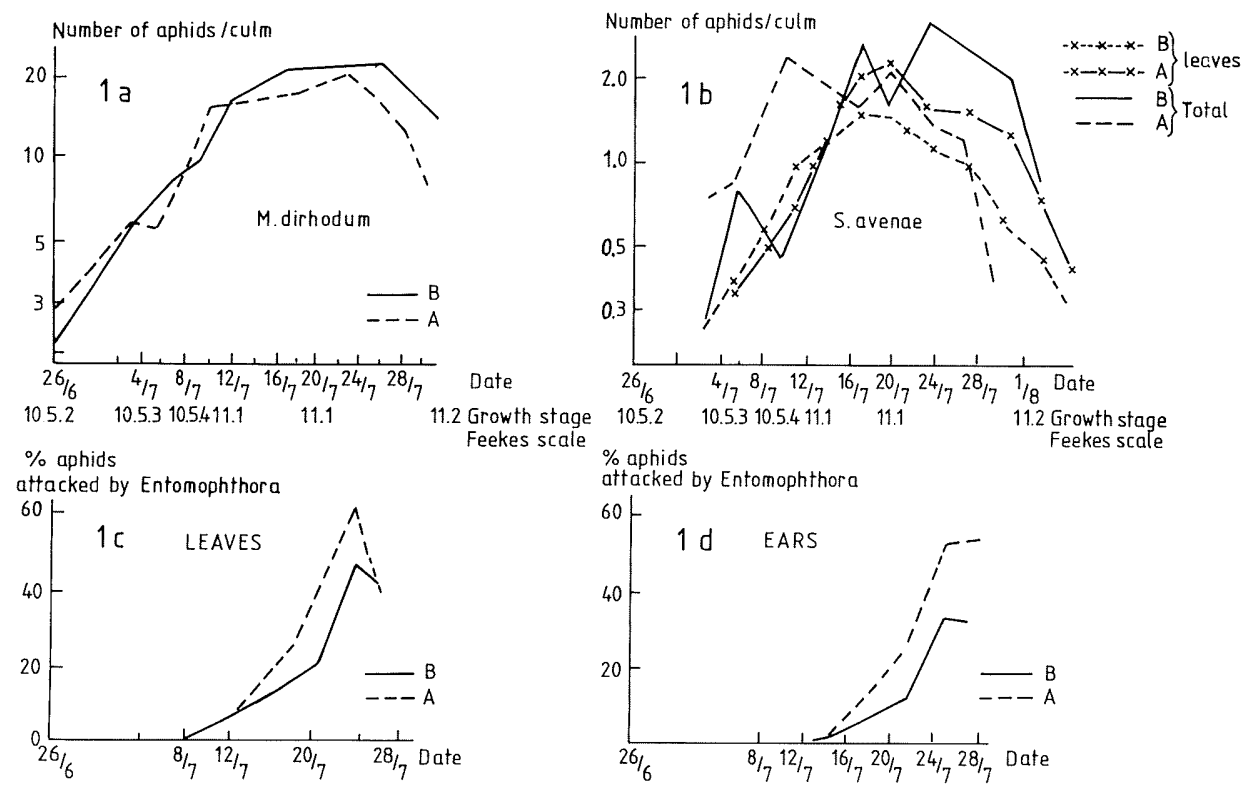

Fig.1. Bladluizendichtheid in de loop der tijd in een veldproef na behandeling $A$ en $B$. Metopolophium dirhodum op de bladeren (la) en het percentage door Entomophthora aangetaste bladluizen (lc). Sitobion avenae op de aren en de bladeren (b) en het percentage door Entomophthora aangetaste bladluizen (1d). 
Fig. 2. Density of yeasts in course of time in field experiment after treatments A, B, C and D. Red yeasts (Sporobolomyces roseus) (2a) and white yeasts (Cryptococcus laurentii var. flavescens) (2b).
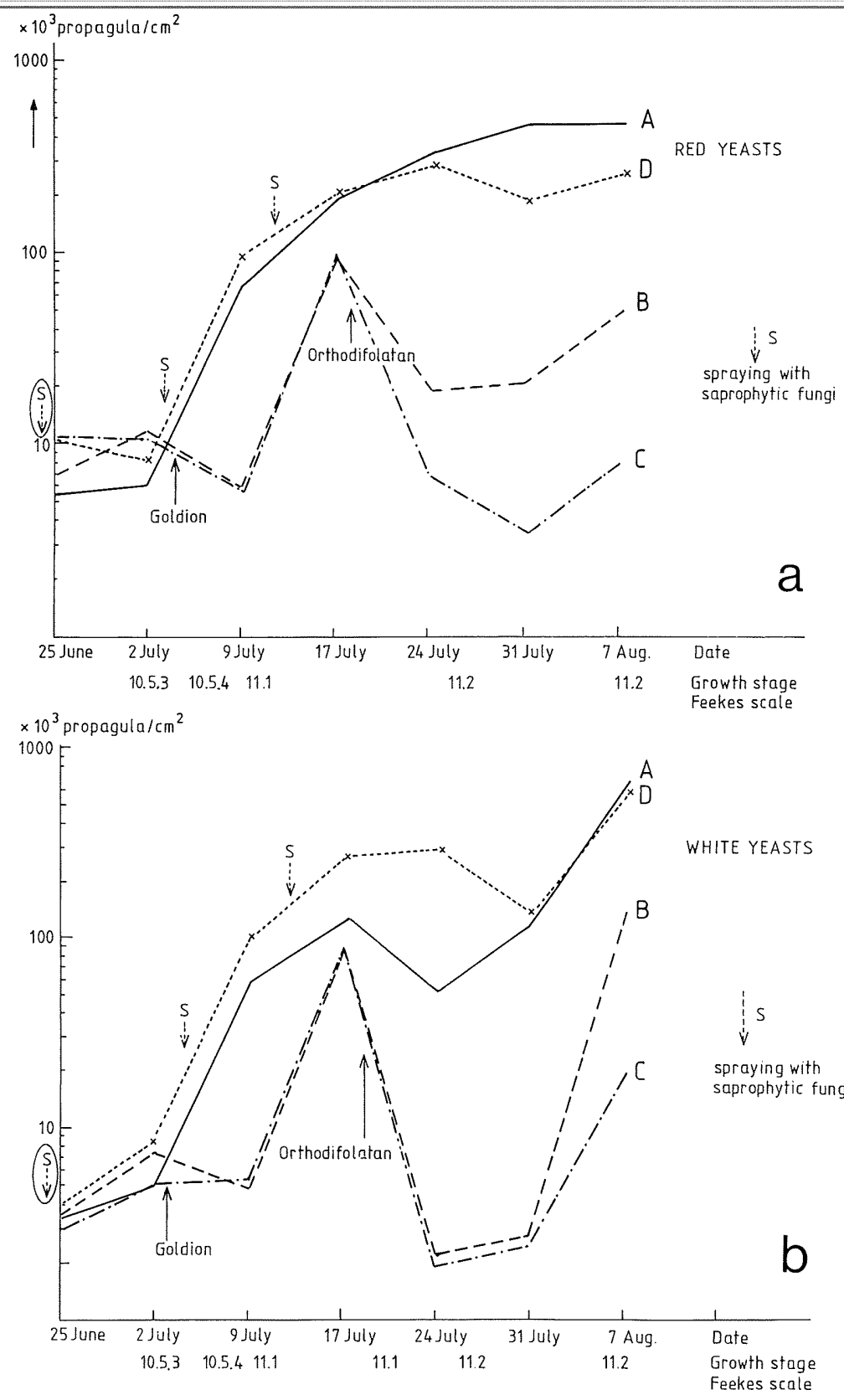

Fig. 2. Dichtheid van de gisten in de loop der tijd in het veldexperiment na de behandelingen $A, B, C$ en $D$. Rode gisten (Sporobolomyces roseus) (2a) en witte gisten (Cryptococcus laurentii var. flavescens) (2b). 
the aphid population but gives some indication of the aphid load experienced by the plants in each of the treatments.

The population curves of white and red yeasts which indicate the level of activity of saprophytic fungi are given in Fig. $2 a+b$. The same levels of colonization were achieved by the application of a fungal suspension in whey (treatment $D$ ) as by natural infection on aphid-honeydew polluted leaves (treatment A). Considerably lower levels of infection were achieved in treatments $B$ and $C$. The number of yeast cells $\mathrm{cm}^{-2}$ of leaf area in plots A and D were similar to densities previously recorded from wheat and rye (Fokkema et al., 1979b). Hyphal fungi were of minor importance since Cladosporium spp. only reached densities of maximally $10^{5} \mathrm{~cm}^{-2}$ in the beginning of August.

Yield. The yields of grain and ear weight obtained in the different treatments are given in Table 7.

Table 7. Yield in grain (16\% water), number of kernels $\mathrm{m}^{-2}$, ear weight, number of kernels per ear and 1000 kernel weight in a field experiment with different treatments.

\begin{tabular}{|c|c|c|c|c|c|c|c|}
\hline \multirow[t]{2}{*}{ Treatments } & \multicolumn{2}{|c|}{$\begin{array}{l}\text { Yield } \\
\left(\mathrm{kg} \mathrm{ha}^{-1}\right)\end{array}$} & \multirow{2}{*}{$\begin{array}{l}\text { Average } \\
\text { number of } \\
\text { kernels } \mathrm{m}^{-2}\end{array}$} & \multirow{2}{*}{$\begin{array}{l}\text { Average } \\
\text { weight per } \\
\text { ear } \\
\text { (g) }\end{array}$} & \multirow{2}{*}{$\begin{array}{l}\text { Number of } \\
\text { kernels per } \\
\text { ear }\end{array}$} & \multicolumn{2}{|c|}{$\begin{array}{l}1000 \text { kernel } \\
\text { weight }(\mathrm{g})\end{array}$} \\
\hline & $\bar{X}$ & s.d. & & & & $\bar{X}$ & s.d. \\
\hline A & 6517 & 226 & 17383 & 1.9 & 51 & 37.5 & 1.5 \\
\hline B & 6516 & 287 & 17004 & 1.9 & 50 & 38.1 & 2.5 \\
\hline $\mathrm{C}$ & 7216 & 233 & 17825 & 2.1 & 52 & 40.5 & 1.7 \\
\hline $\mathrm{D}$ & 6901 & 244 & 17364 & 2.0 & 51 & 39.7 & 1.1 \\
\hline
\end{tabular}

Tabel 7. Korrelopbrengst (16\% vocht), aantal korrels $\mathrm{m}^{-2}$, aargewicht, aantal korrels per aar en 1000 korrelgewicht in een veldexperiment met verschillende behandelingen.

To linearize the assumed multiplicative effects of treatments on yield a log transformation was done. This assumption of multiplicative effects was based on the production-ecological observation that the effect of damage causing organisms is non-linearly related to the yield levels of the non-treated plots. The processed data were used in a one way analysis of variance. This analysis showed that the ratios of the yields in the various treatments were significantly different at the $95 \%$ level.

To test the differences pair by pair a Student Newman Keuls multiple range test was used (Table 8 ). The yield ratios between $\mathrm{D}$ and $\mathrm{C}$ were significantly different from 1 at the $10 \%$ level; C, D and A, B were significantly different at the $1 \%$ level. Both aphids and fungi caused a decrease in grain yield. This decrease was mainly due to differences in the 1000 kernel weight (Table 8). A one way analysis of variance of $\log 1000$ kernel weights gave significant differences between treatments and the multiple range test showed that treatments $\mathrm{A}$ and $\mathrm{C}, \mathrm{D}$ and $\mathrm{A}, \mathrm{D}$ and $\mathrm{B}$, and $\mathrm{B}$ and $\mathrm{C}$ were significantly different at the $1 \%$ level. This was not so for treatments D and C, not even at the $10 \%$ level. A regression analysis of 1000 kernel weight versus yield resulted in a low correlation $\left(r^{2}=0.6\right)$. Therefore we conclude that the differences 
Table 8. Results of the Student Newman Keuls multiple range test of differences of ratios between treatment A, B, C and D (based on the results presented in Table 7), pair by pair (the confidence value is given; - no significant difference at the $10 \%$ level).

\begin{tabular}{|c|c|c|c|c|c|c|c|c|}
\hline & \multicolumn{4}{|c|}{ Yield } & \multicolumn{4}{|c|}{1000 kernel weight } \\
\hline & $\mathrm{A}$ & B & $\mathrm{C}$ & $\mathrm{D}$ & $\mathrm{A}$ & B & $\mathrm{C}$ & $\mathrm{D}$ \\
\hline A & $\mathrm{X}$ & - & 0.01 & 0.01 & $x$ & - & 0.01 & 0.01 \\
\hline B & - & $X$ & 0.01 & 0.01 & - & $X$ & 0.01 & 0.01 \\
\hline $\mathrm{C}$ & 0.01 & 0.01 & X & 0.1 & 0.01 & 0.01 & $\mathrm{X}$ & - \\
\hline D & 0.01 & 0.01 & 0.1 & $\mathrm{X}$ & 0.01 & 0.01 & - & $\mathrm{X}$ \\
\hline
\end{tabular}

Tabel 8. Resultaten van de Student Newman Keuls breedtetoets op de verschillen van de verhoudingen tussen behandeling $A, B, C$ en $D$ (gebaseerd op de resultaten vermeld in Tabel 7), paarsgewijs (het betrouwbaarheidsniveau is gegeven).

in 1000 kernel weight were not the only cause of differences in grain yield. The number of kernels $\mathrm{m}^{-2}$ at the start of kernel filling was hardly affected by the treatments. This was expected, as aphids and fungi were only present after flowering when kernel number is set (Evans et al., 1975). However, some effect on kernel number might result from the abortion of smaller kernels and the presence of unharvestable small kernels. There was little difference in the grain yield from A and B treatments, although the aphid numbers on these two treatments differed considerably. Apparently the effect caused by the differences in aphid abundance on these two treatments was counterbalanced by the presence of fungi on the A plots. When the assumption is made that the yield loss due to aphid and honeydew was proportional with the number of aphid days, the yield loss on A due to aphids and honeydew alone could be computed as the ratio of aphid days after treatments $\mathrm{A}$ and $\mathrm{B}$ multiplied by the difference in yield between plots $\mathrm{C}$ and $\mathrm{B}$ :

$$
\frac{434}{593} \times 700 \approx 500 \mathrm{~kg} \mathrm{ha}^{-1}
$$

The effect of fungi on A plots amounted then to $700-500=200 \mathrm{~kg} \mathrm{ha}^{-1}$. The circa $300 \mathrm{~kg} \mathrm{ha}^{-1}$ difference in yield between plots $\mathrm{C}$ and $\mathrm{D}$ confirms the assumption of counterbalancing of aphid and saprophytic fungi effects. Thus of the loss of grain yield in treatment $\mathrm{A}, 28 \%$ was due to fungi and $72 \%$ due to the effects of aphids and honeydew.

Photosynthesis and ageing. Measurements of photosynthesis in the crop enclosures resulted in 15 light response curves per treatment. These response curves were used to calculate the light use efficiency and the maximum assimilation rate. In many cases satiation was not reached and the analysis of the light response curves as used in the laboratory studies is then inaccurate. Comparison over a period of time was difficult because the effect of the ageing of the foliage interacted with the direct effects of aphid feeding. Integration of the effects by a computer simulation model for crop growth did not make sense because of the variability within the treatments 
and the changes in course of time. Therefore, only the light use efficiencies have been compared, which did not seem to be different (Table 9). A comparison of maximum assimilation rates was difficult as leaf areas were considerably different in the different plots.

Table 9. Results of photosynthesis measurements with a crop enclosure, in the field experiment with different treatments.

\begin{tabular}{lll}
\hline Treatment & $\begin{array}{l}\text { Crop development stage } \\
\text { after Feekes (Large, 1954) }\end{array}$ & $\begin{array}{l}\text { Light use efficiency in } \\
\mathrm{kg} \mathrm{CO}_{2} \mathrm{~J}^{-1} \mathrm{ha}^{-1} \mathrm{~h}^{-1} \mathrm{~m}^{2} \mathrm{~s}\end{array}$ \\
A & 10.5 .4 & 0.44 \\
& 11.1 & 0.51 \\
B & 10.5 .4 & 0.48 \\
& 11.1 & 0.49 \\
C & 10.5 .4 & 0.47 \\
& 11.1 & 0.50 \\
D & 10.5 .4 & 0.42 \\
& 11.1 & 0.46
\end{tabular}

Tabel 9. Resultaten van fotosynthesemetingen met een gewaskamer, in de veldproef met verschillende behandelingen.

Absence of difference in the photosynthetic rates could result from the accuracy of the measuring equipment, as only differences of more than $3 \mathrm{~kg} \mathrm{ha}^{-1} \mathrm{~h}^{-1}$ are detectable. Periodic harvests indicated that the differences in yield between the treatments were achieved in the 20 days from 20 July to 10 August (Fe 11.1 to $\mathrm{Fe} 11.2$ ). If the difference in yield was due to differences in photosynthetic activity only, the following calculation holds. A difference of $700 \mathrm{~kg} \mathrm{ha}^{-1}$ is equivalent to $35 \mathrm{~kg} \mathrm{ha}^{-1}$ day $^{-1}$ when achieved in 20 days, or $3 \mathrm{~kg} \mathrm{ha}^{-1} \mathrm{~h}^{-1}$ assuming an effective daylength of $12 \mathrm{~h}$. The direct effect of aphid feeding may explain $45-50 \%$ of the loss in yield (Vereijken, 1979; Rabbinge and Vereijken, 1980), so that effects due to a lowering of the photosynthetic activity is equivalent to $1.5 \mathrm{~kg} \mathrm{ha}^{-1} \mathrm{~h}^{-1}$ which is too low to be recorded by the equipment used $\left(3 \mathrm{~kg} \mathrm{ha}^{-1} \mathrm{~h}^{-1}\right)$. Only when aphid numbers are very high and their indirect effects on photosynthetic rates considerable, will it be measurable using crop enclosures. It may be more appropriate to use leaf chambers to measure photosynthetic rates in the field rather than making such measurements on groups of plants.

Changes in leaf area index (LAI) in time were determined as a by-product of the photosynthetic measurements in the crop enclosures. The results show a slightly faster decrease in LAI in treatment $A$ than in treatment $C$, which may indicate that the leaf area duration was shorter in plots experiencing treatment A (Table 10). This confirms the findings of Wratten (1975). 
Table 10. Regression line and correlation coefficient for the leaf area index of the different treatments in the field experiments in relation to time, expressed in days from watery ripe.

$\begin{array}{llll}\text { Treatment } & \text { Regression tine } & \begin{array}{l}\text { Corretation } \\ \text { coefficient }\end{array} & \begin{array}{l}\text { Standard } \\ \text { error }\end{array} \\ \text { A } & \mathrm{y}=4.87-0.144 \mathrm{x} & 0.95 & 0.0237 \\ \mathrm{~B} & \mathrm{y}=4.89-0.153 \mathrm{x} & 0.92 & 0.0327 \\ \mathrm{C} & \mathrm{y}=4.01-0.089 \mathrm{x} & 0.98 & 0.0087 \\ \mathrm{D} & \mathrm{y}=4.91-0.137 \mathrm{x} & 0.99 & 0.0095\end{array}$

Tabel 10. Regressielijn en correlatiecoëfficiënt voor de LAI versus tijd in dagen vanaf waterrijp bij verschillende behandelingen in de veldproef.

\section{Discussion}

Both field and laboratory experiments indicate that aphids damage wheat directly by the removal of plant sap and indirectly by their excreta. Our laboratory experiments reveal that the effects of honeydew on photosynthesis and on ageing of the leaves, and the effects of fungi, flourishing on this honeydew, can be considerable. In the field experiments $72 \%$ of the yield losses could be attributed to aphid feeding and honeydew and $28 \%$ to saprophytic fungi. Saprophytic fungi feeding on aphid honeydew may have caused a loss of about $200 \mathrm{~kg} \mathrm{ha}^{-1}$ out of the $800 \mathrm{~kg}$, or $25 \%$, which is considerably less than the $50 \%$ reported by Vereijken (1979). Although fungi affected yield, it is not known to what extent saprophytes and necrotrophic pathogens, both equally sensitive to captafol, contributed to this loss. The latter group of fungi has not been quantified in this experiment. The direct effect of feeding by aphids is important but variable, and should be studied in more detail to elucidate the size of the effect and its dependence on the stage of growth and condition of the wheat plant.

The effect of honeydew on gross assimilation rate observed in the laboratory could not be established in the field, possibly because the order of difference between treatments was too small to be measured by the apparatus used. Another cause of the absence of measurable differences may be rainy weather during a part of the grain filling period. Rain may have reduced the amount of honeydew on the crop. A third reason for the discrepancy between laboratory and field photosynthesis measurements may lay with the used methods in the laboratory trials. A manual introduction of honeydew may induce itself an effect on photosynthesis. Leaf area duration is shortened in the field and in the laboratory, as a result of the presence of aphids and their honeydew. Probably this effect on leaf area duration is a major indirect effect of the cereal aphids. This effect is aggrevated by the secondary saprophytic fungi which may cause a further decrease in leaf area duration.

The exact extent of aphid damage to wheat is still unknown. To improve the value of warning and damage thresholds for aphids, better information is needed on the relation of secondary effects to weather factors, as the importance of these effects differs between fields and between years due to variation in weather.

The finding that spraying with captafol has an effect on maximum population level of the aphids makes clear that sprayings with fungicides may cause unwanted 
side effects. Schedule-spraying should therefore be abandoned and spraying intensity should be lowered.

\section{Acknowledgements}

We like to thank W.P. Mantel, J. Jansen, G.W. Ankersmit, N.J. Fokkema, J. Sinke and J.W.J. Akkersdijk for close cooperation and rearing of plants, aphids and fungi and C.A. Hoveyn for help with statistical analysis. We gratefully mention Prof. A.F.G. Dixon who improved our text considerably and thank Bert van Amersfoort for typing the manuscript.

\section{Samenvatting}

\section{Schade door graanbladluizen in tarwe}

Laboratorium- en veldproeven over de schade door bladluizen in tarwe worden beschreven. Een analyse van de directe en indirecte effecten van bladluizen op de groei van het gewas werd verricht. In het laboratorium werd een duidelijk effect van honingdauw en gisten op de fotosynthese gevonden. Dit effect kon niet worden gedemonstreerd in het veld, hetgeen waarschijnlijk wordt veroorzaakt door de orde van grootte van dit effect dat valt binnen de meetfout van de gewasfotosyntheseapparatuur.

Het effect van honingdauw op veroudering, dat in het laboratorium werd vastgesteld, kon ook worden aangetoond in het veld en is waarschijnlijk een van de hoofdoorzaken van de oogstverliezen. Deze oogstverliezen in het veld bedroegen $700 \mathrm{~kg} \mathrm{ha}^{-1}$ bij een maximale dichtheid van 35 bladluizen per halm en werden voor $72 \%$ veroorzaakt door directe zuigschade en honingdauweffecten. Van de totale schade werd $28 \%$ veroorzaakt door saprofytische en wellicht ook door enige necrotrofe schimmels. De precieze bijdrage van ieder van de schadefactoren tot de schade werd niet vastgesteld, maar de wijze waarop directe en indirecte effecten hun bijdrage leverden aan de uiteindelijke oogstverliezen werd zichtbaar gemaakt.

\section{References}

Bardner, R. \& Fletcher, K.E., 1974. Insect infestations and their effects on the growth and yield of field crops, a review. Bull. ent. Res. 64: 141-160.

Carter, N., Mc Lean, I.F.G., Watt, A.D. \& Dixon, A.F.G., 1980. Cereal aphids; a case study and review. Appl. Biol. 5. Vol. V. T.H. Coaker (Ed.), Acad. Press.

Carter, N. \& Rabbinge, R., 1980. Simulation models of the population development of Sitobion avenae. WPRS Bulletin 1980/III/4, 92-98.

Carter, N., Rabbinge, R. \& Dixon, A.F.G. Cereal aphid populations, biology, simulation and prediction. Simulation Monographs Pudoc, Wageningen, in press.

Evans, L.T., Wardlaw, I.F. \& Fisher, R.A., 1975. Wheat. In: L.T. Evans (Ed.), Crop physiology. Cambr. Univ. Press: 101-149.

Fokkema, N.J., Houter, J.G. den, Kosterman, Y.J.C. \& Nelis, A.L., 1979a. Manipulation of yeasts on field grown wheat leaves and their antagonistic effect on Cochliobolus sativus and Septoria nodorum. Trans. Br. mycol. Soc. 72: 19-29. 
Fokkema, N.J., Kastelein, P. \& Post, B.J., 1979b. No evidence for acceleration of leaf senescence by phyllosphere saprophytes of wheat. Trans. Br. mycol. Soc. 72: 312-315.

Goudriaan, J. \& Laar, H.H. van, 1978. Calculation of daily totals of the gross $\mathrm{CO}_{2}$ assimilation of leaf eanopies. Neth. J. agrie. Sei. 26: 373-382.

Large, E.C., 1954. Growth stage of cereals, illustration of the Feekes scale. Pl. Path. 3: 128129.

Louwerse, W. \& Eikhoudt, J.W., 1975. A mobile laboratory for measuring photosynthesis, respiration and transpiration of field crops. Photosynthetica 9: 31-34.

Louwerse, W. \& Oorschot, J.L.P. van, 1969. An assembly for routine measurements of photosynthesis, respiration and transpiration of intact plants under controlled conditions. Photosynthetica 3: 305-315.

Rabbinge, R., Ankersmit, G.W. \& Pak, G.A., 1979. Epidemiology and simulation of population development of Sitobion avenae in winter wheat. Neth. J. Pl. Path. 85: 197-220.

Rabbinge, R. \& Mantel, W.P., 1981. Monitoring for cereal aphids in winter wheat. Neth. J. Pl. Path. 87: 25-29.

Rabbinge, R. \& Vereijken, P.H., 1980. The effect of diseases or pests upon the host. Z. PflKrankh. PflSchütz 87(7): 409-422.

Rautapåa, J., 1966. The effect of the English grain aphid Macrosiphum avenae on the yield and quality of wheat. Ann. Agric. Fenn. 5: 334-341.

Vereijken, P.H., 1979. Feeding and multiplication of three cereal aphid species and their effect on yield of winter wheat. Agric. Res. Rep. 888, Pudoc, Wageningen.

Vickerman, G.P. \& Sunderland, K.D., 1977. Some effects of dimethoate on arthropods in winter wheat. J. appl. Ecol. 14: 767-777.

Vickerman, G.P. \& Wratten, S.P., 1979. The biology and pest status of cereal aphids in Europe: a review. Bull. ent. Res. 69: 1-32.

Wit, C.T. de, 1965. Photosynthesis of leaf canopies. Agric. Res. Rep. 663, Pudoc, Wageningen.

Wratten, S.D., 1975. The nature of the effects of the aphids Sitobion avenae and Metopolophium dirhodum on the growth of wheat. Ann. appl. Biol. 79: 27-34.

Wratten, S.D., 1978. Effects of feeding position of the aphids Sitobion avenae and Metopolophium dirhodum on wheat yield and quality. Ann. appl. Biol. 90: 11-20.

\section{Address}

Vakgroep Theoretische Teeltkunde, Landbouwhogeschool, P.O. Box 430, 6700 AK Wageningen, the Netherlands. 